\title{
Adenine Phosphoribosyltransferase Deficiency
}

National Cancer Institute

\section{Source}

National Cancer Institute. Adenine Phosphoribosyltransferase Deficiency. NCI Thesaurus. Code C121564.

An inherited condition caused by mutations in the APRT gene that affects the kidneys and urinary tract. The most common feature of this condition is recurrent kidney stones. 